\title{
"A guerra ia nos seguindo como a nossa própria sombra": Brecht no exílio dinamarquês
}

\author{
"The war followed us like a shadow": Brecht in danish exile
}

Débora El-Jaick Andrade

Doutora em História Social pelo PPGH-UFF

Professora Associada da Universidade Federal Fluminense

debandrade.andrade54@gmail.com

\begin{abstract}
Resumo: O artigo versa sobre o período de 1933-1939 quando o poeta, dramaturgo e crítico teatral Bertolt Brecht exilou-se na Dinarmaca, a partir da ascensão do Partido Nacional Socialista ao poder na Alemanha (1933). Aborda o exílio como um tema historiográfico e sociológico e como fenômeno histórico no século XX. Caracteriza o período da República de Weimar como favorável às vanguardas artísticas, ao pensamento liberal, quando Brecht estabeleceu os princípios do seu teatro épico. Todo o intenso desenvolvimento teatral foi interrompido pela política de "alinhamento" que determinou a emigração dos maiores nomes da intelectualidade alemã. No exílio desde 1933, Brecht caracterizou a condição do exilado político e realizou a crítica ao nazifascismo através da poesia e da dramaturgia, em cartas, poemas, diários de trabalho. Através da abordagem da história intelectual é possível depreender a evolução de seu pensamento, assim como relações de amizade e solidariedade entre emigrados que consistiam em uma forma fundamental de sobrevivência, no sentido de atenuar o isolamento e permitir a continuidade dos trabalhos literários. Para Brecht, uma tarefa fundamental era mobilizar os emigrados, romper o conformismo, aproveitar-se de sua projeção literária para combater o regime nazista de fora do país.
\end{abstract}

Palavras Chaves: Intelectuais, exílio, Bertolt Brecht, Nazismo
Abstract: This article examines the period between 1933-1939 when Poet, drama author and critic Bertolt Brecht sought exile in Denmark, as National Socialist Party rose to power. It approaches exile as a historical and sociological topic and as a XXth century historical phenomenon. It characterizes the period of the Weimar republic as favorable to the artistic vanguards, to liberal thoughts, when Brecht established the principles of epic theatre. These flourishing development in theatre, disrupted by the politics of coordination which determined the emigration of the best intellectuals of the time in Germany. In exile since 1933 Brecht characterized the condition of the political exiled and reflected on the nature of Nazism in his letters, poems, work diaries. Through recurrence to intellectual history we seek to recognize the evolution of his thoughts, as well as friendship and solidarity relations within the german intellectual community in exile, which was a way to survive in the sense that they helped to soften the condition of isolation and allowed him to continue his literary works. Besides, thanks to those relations Brecht kept acting politically and denouncing fascism through poetry and drama. For Brecht, a main task was to mobilize the émigrés, to break out from conformity, to benefit from their literary fame to oppose Nazi regime abroad.

Keywords: Intelectuals, exile, Bertolt Brecht Nazism. 


\section{Introdução}

Em 30 de janeiro de 1933, quando Adolf Hitler tornou-se chanceler, um grande número de artistas e intelectuais alemães antecipou que a liberdade de que gozara nos tempos progressistas da República de Weimar havia chegado ao fim e trilhou o caminho do exílio. Esta comunidade intelectual tão brilhante se dispersou e participou de forma diversa no combate ao ideário nazifascista. Dentre estes, há notáveis intelectuais associados ao marxismo, Walter Benjamin, Theodor W. Adorno, Karl Korsch, que eram bastante visados pelo regime fortemente anticomunista. Era este o caso de Bertolt Brecht, que aos 35 anos refugiou-se na Dinamarca a espera de que as contradições irromperiam e chegariam ao ponto de colocar fim às aventuras totalitárias do Partido Nacional Socialista dos Trabalhadores Alemães. Porém, o partido perpetuou-se no poder, o exército alemão ocupou países vizinhos, submetendo as populações locais, obrigando a família de Brecht a deslocar-se pelos países nórdicos até alcançar os Estados Unidos em $1941^{1}$.

A estadia em Svendborg, na Dinarmarca significou uma inflexão na produção literária de Brecht no sentido que, como explica John White, ele abandonou a ênfase nas questões econômicas, de transformação social e de socialização dos meios de produção cultural em sua teoria do teatro épico e dedicou-se aos aspectos da forma e da função dramática $^{2}$. (WHITE, 2004:78). Além disto, a experiência do exílio interrompe os experimentos que vinha realizando e ele volta seus esforços para a denúncia dos crimes do nazismo.

O exílio foi um fenômeno marcante no século XX, de modo que tem sido objeto de análise sociológica e historiográfica, desde que Georg Simmel, estudioso de uma sociologia das formas de socialização, escreveu seu ensaio O Estrangeiro (1908). Nesta data, as guerras mundiais ainda não haviam tornado o exilado e o refugiado em um personagem trivial na paisagem europeia. ${ }^{3}$ Em meados do século XX, Theodor W. Adorno, ele mesmo um judeu exilado do regime nazista, escreveu uma autobiografia

\footnotetext{
${ }^{1}$ Os alemães incorporaram a Tchecoslováquia, anexaram a Áustria através de referendo e invadiram a Polônia.

${ }^{2}$ White analisa, sobretudo, a disputa com o método performático dos stanislavskianos, que estimula Brecht a teorizar de forma mais sistemática teatro épico, no que toca a metodologia e a apresentação.

3 Para Simmel (2005), o estrangeiro, apesar de membro do grupo social, não é considerado alguém pertencente a este grupo, mas a outro grupo determinado. Ele é visto e sentido como alguém absolutamente móvel, não se encontra vinculado organicamente a nada e a ninguém, e por isto, as relações e contatos, quando ocorrem, se dão a partir de um parâmetro de distanciamento objetivo.
} 
Minima Moralia (1951) em que atesta que o intelectual exilado é um deslocado procurando sobreviver em uma cultura de massa, que se recolhe ao isolamento da vida privada ${ }^{4}$. A condição de banido, para Adorno, o torna uma figura exemplar da "vida mutilada", das contradições da modernidade. Através do distanciamento, no entanto, lhe é permitido recusar à vida cotidiana transformada em mercadoria, encontrando um lar na escrita. (SAID, 2003:57)

Mais recentemente, Edward Said, intelectual de origem palestina, importante expoente dos estudos culturais e do pensamento pós-colonial, tece considerações sobre a condição do exílio, considerando-o o reverso do nacionalismo. Segundo o autor, a moderna cultura ocidental é, em larga medida, obra de exilados, emigrantes, refugiados, pois o pensamento acadêmico, intelectual e estético em vários lugares, como nos Estados Unidos, elevou-se graças aos refugiados do fascismo, do comunismo e de outros regimes que expulsaram os dissidentes. Isto fez do século XX a era do refugiado, da migração em massa, dos deslocados. Não obstante, o historiador palestino propõe algumas distinções entre exilados, refugiados, expatriados e emigrados, estabelecendo que os refugiados são uma criação do Estado do século XX e que o termo possui um sentido político, considerando-os como gente inocente e desnorteada que precisa de ajuda internacional. Por outro lado, os exilados foram sujeitos ao banimento, portam o estigma de serem forasteiros, enquanto os expatriados e emigrados moram voluntariamente em outro país, geralmente por motivos pessoais ou sociais. Eles podem sentir a mesma solidão e alienação do exilado, mas não sofrem pelas rígidas interdições.

Outrossim, a existência do exilado é descontínua; separado de suas raízes, sente uma necessidade urgente de reconstituir sua vida rompida, tentando compensar a perda desorientadora, criando um novo mundo literário para si. Said observa: "Não surpreende que tantos exilados sejam romancistas, jogadores de xadrez, ativistas políticos e intelectuais. Agarrando-se à diferença como a uma arma, o exilado insiste em seu direito de se recusar a pertencer a outro lugar." (SAID, 2003:53) De fato, o intelectual não deseja ser assimilado, embora receba a oferta de um novo conjunto de afiliações e novas lealdades.

\footnotetext{
${ }^{4}$ Em Minima Moralia Adorno descreve o exilado: "Vive num ambiente que lhe deve permanecer incompreensível, por mais que saiba das organizações sindicais ou do tráfego urbano; estará sempre desorientado. Entre a reprodução da sua própria vida sob o monopólio da cultura de massas e o trabalho responsável há um hiato irreconciliável. Descaracterizada é a sua língua e sepultada está a dimensão histórica onde o seu conhecimento ia buscar forças".p.22
} 
Said constata que, se historicamente houve aqueles que se adaptaram e obtiveram êxito profissional, outros preferiram permanecer à margem das correntes dominantes, não se acomodar e resistir. Esses são igualmente apartados no que se refere aos privilégios, poder e honrarias que pode proporcionar uma carreira institucional estável e regular. É aí que reside o aspecto positivo da condição do exilado segundo Said: o exílio inspira ao movimento devido à instabilidade que produz, induz a uma reinvenção da própria trajetória, assim como a uma avaliação das coisas a partir de uma dupla perspectiva e da justaposição de experiências culturais. (SAID, 2005:67-68)

O filósofo Tzvetan Todorov lança luz sobre outro aspecto da condição do exilado em seu livro $O$ Homem desenraizado, a partir de sua experiência como búlgaro radicado em Paris no final dos anos 1960. Todorov é ele mesmo o homem desenraizado, que tem em si dois países e duas culturas, sofre um fenômeno que ele denominou de dupla vinculação, possuindo o sentimento de ser um imigrante estrangeiro na própria terra natal. A dificuldade que se coloca para o indivíduo nesta posição se deve a inautenticidade do seu discurso, já que cada um dos discursos, o da terra natal e o da pátria abraçada; ele corresponderia à metade de um ser incompleto.(TODOROV,

O cientista político Laurent Jeanpierre contesta a qualificação positiva atribuída ao deslocamento pelas ciências sociais no pós-1968, avaliando que o exílio deixa de ser interpretado como traição à pátria e adquiriu conotação política. A ideia de mobilidade é valorizada, assim como de "desterritorialização", de "nomadismo", associadas à capacidade crítica ou inovadora, ao encontro de culturas e à emergência de um novo cosmopolitanismo. Para ele, o uso da categoria de exilado ou de nômade tornou-se metáfora da condição pós-moderna, em um contexto em que se fazia o elogio da mundialização e do neoliberalismo. Como constata Jeanpierre, o discurso do "nomadismo" não é um discurso de verdade, ele preenche uma função ideológica. Na realidade, dificilmente as fronteiras reais e simbólicas são penetráveis e as hierarquias locais erradicadas. Raras são as pessoas que podem ou sabem habitar a exterritorialidade ou viver continuamente entre-dois-mundos, pois jamais voltariam ao local de origem. Ele recusa o suposto hibridismo das culturas contemporâneas afirmando que, na verdade, não existe nenhuma interferência de uma cultura sobre a outra dentro de uma sociedade, ou entre diversos países. (JEANPIERRE, 2008:189)

Da mesma forma que o conceito foi objeto de reflexão, uma gama de autores 
tem abordado o tema do exílio de escritores refugiados do nazismo. Ana Pérez, na coletânea que organizou de textos dos escritores alemães emigrados El exilio alemán. Textos literarios y políticos (2008) ${ }^{5}$ que oferecem as distintas visões do exílio, da ascensão do nazismo e da Alemanha. Também investigaram o destino dos exilados judeus Martin Jay no livro Permanent Exiles: Essays on the Intellectual Migration from Germany to America (1985) e Enzo Traverso em La pensée dispersée. Figures de l'exil juif (2004). Há uma bibliografia especificamente centrada em Brecht no exílio, como a obra de James K. Lyon Bertolt Brecht in America (1980), Brecht in Exile de Bruce Cook (1982), Bertolt Brecht, caos acording to plan (1987) de John Fuegi, Brecht's Poetry of Political Exile (2010), editado por Ronald Speirs, Benjamin e Brecht. História de uma amizade (2004) de Erdmut Wizisla, assim como a obra recentemente traduzida para o português pela editora Boitempo, Ensaios sobre Brecht de Walter Benjamin que traz vários estudos críticos. Além destes, duas biografias, de Frederic Ewen, Bertolt Brecht, sua vida sua arte e seu tempo (1991) e A Brecht: a literary life (2014) de Stefen Parker, dedicam razoável espaço ao período do exílio, abordando as afinidades políticas e as contendas literárias.

Neste ensaio que faz parte da pesquisa institucional "Intelectuais em tempos sombrios: estudos sobre política e cultura em Benjamin, Brecht e Adorno", realizada desde 2017 no âmbito do Laboratório de História, Política e Cultura da Universidade Federal Fluminense (RJ), abordamos a experiência de Brecht no exílio dinamarquês a partir da perspectiva da história intelectual proposta por François Dosse, que surge do intercruzamento de uma história das ideias, de uma história das mentalidades e de uma história cultural. Dispondo de conectores como, "meios de sociabilidade" e "geração" e considerando todos os suportes culturais (DOSSE, 2004: 19), a história intelectual, sobretudo francesa, valoriza a dimensão política, a inserção institucional e o engajamento dos escritores e autores, sem desprezar as formas discursivas em relação a um marco sociopolítico e mental, para localizar todo o pensamento como ato de enunciação solidário de um contexto. (DOSSE, 2004) Dosse também se dedicou a compor a biografia intelectual, que permite compreender o sentido de uma vida, significado que nunca é unívoco e só pode ser aprendido no plural, a partir da recepção e das impressões dos que com ele travaram contato e de apropriações de sua obra.

\footnotetext{
${ }^{5}$ Há também outras obras como MAUTHNER, Martin.German writers in the French Exile. 1933-1940. London/Portland: Vallentine Mitchell, 2007; ZÜHLSDORF, Volkmar. Hitler's exiles. The German Cultural Resistence in America and Europe. London, Continuum, 1999.
} 
(DOSSE, 2009: 375) Para efetuar satisfatoriamente esta tarefa, a contextualização inclusive o ambiente intelectual - pode dar substância aos conceitos e localizá-los a partir de uma leitura diacrônica que valoriza a coerência interna de uma obra constituída ao longo do tempo. (DOSSE, 2009: 377)

A partir destas referências, selecionamos na correspondência ativa, cartas que permitem traçar as redes de sociabilidades, que evidenciam relações de parceria e solidariedade, diários de trabalho que perfazem modalidades de escrita de si e de memória pessoal e, além disto, dão conta não apenas do cotidiano, mas de inquietações de natureza íntima. Na sociedade moderna há uma forte inclinação dos sujeitos a atribuírem significados especiais ao mundo em torno, relacionados com suas próprias vidas (GOMES, 2004:11), sobretudo em se tratando de escritores no auge de sua produtividade, obrigados a levar existências apartadas de seu público e língua materna.

Procedemos de tal forma com o intuito de aceder às subjetividades dos sujeitos, buscamos reconstituir as sensibilidades e estratégias de sobrevivência em condições adversas, as formas do intelectual experienciar o drama do exílio que é, ao mesmo tempo uma condição vivida individual e coletivamente, cujos infortúnios são observáveis no relato do cotidiano, assim como nos comentários sobre os acontecimentos imediatos da política e sobre o bloco histórico ${ }^{6}$. Interessa-nos os meios que encontrou para romper o isolamento e agir politicamente, agir que compreende dar uma nova orientação a sua produção literária em um contexto adverso em que a denúncia do regime nazista tornara-se premente.

\section{O deslocamento como fenômeno histórico contemporâneo}

1920 foi uma década de recomeço, em que nada mais seria como antes. Depois que o Tratado de Versailles - acordos que colocaram fim à Primeira Guerra Mundial redesenhou o mapa da Europa, impérios centenários foram dissolvidos, como o Império Austro Húngaro, o Império Otomano e o Império Russo, grandes Estados perderam parte de seu território, ao mesmo tempo em que os países derrotados foram submetidos a duras reparações de guerra. As nações beligerantes não haviam se preparado para acolher os veteranos, muitas vezes mutilados, e integrá-los ao mercado de trabalho, em

\footnotetext{
${ }^{6}$ Este termo de Antônio Gramsci que encontra-se nos Cadernos do Cárcere refere-se à relação, sempre recíproca e dialética, entre estrutura e superestrutura, entre teoria e prática, entre forças materiais e ideologia.
} 
uma conjuntura em que o desemprego era o grande flagelo. (FERRO,1969: 379) O avanço do socialismo, após a Revolução Russa, de um lado, e do liberalismo democrático, de outro, provocou reações autoritárias durante a década que se seguiu. Os revanchismos se nutriam do ressentimento pela aceitação de toda a responsabilidade da Alemanha pela guerra, cláusula prevista no tratado de paz, e por uma derrota que nunca foi plenamente admitida pelas tropas militares (FERRO, 1969: 375).

No pós-guerra, a dispersão da população acompanhou a desagregação de um conjunto de referências culturais que a geração do início do século conhecia e compartilhava. A instabilidade política, econômica, social contrastava com a aparente perenidade dos impérios e dinastias, com inabalável confiança na ciência moderna e no progresso, gerando impotência diante da destruição bélica sem precedentes causada pela guerra industrial. Em decorrência do conflito, países foram ocupados, alguns extintos e outros criados ao seu término, nacionalidades foram redefinidas, povos foram deslocados, como por exemplo, os refugiados belgas da Primeira Guerra ${ }^{7}$. Diante da ausência de braços, centenas de milhares de sujeitos de vários continentes apresentaram-se para trabalhar fora de seus lugares de nascimento.

Ao todo foram 12 milhões de civis deslocados ${ }^{8}$, expatriados, prisioneiros de guerra, milhões de refugiados franceses, russos, belgas, italianos e 1 milhão de armênios varridos da Turquia, centenas de milhares de judeus expulsos da Rússia e do Império Austro Húngaro. Diante do trânsito populacional, os Estados intensificaram o controle e adotaram medidas de restrição migratória na década seguinte, sobretudo a Alemanha, Itália e Estados Unidos. (McKEOWN, 2004: 172) O nacionalismo e o policiamento das fronteiras territoriais eram, de fato, parte do mesmo processo que produziu imigração, as barreiras foram erguidas, construindo o medo da contaminação cultural, da queda nos níveis de vida e da subversão política. (McKEOWN, 2004:174). A perseguição política a anarquistas e socialistas, que emigraram ou acabaram deportados para os países de origem foi outro fator que contribuiu para o incremento da vigilância nos anos 1920.

O destino dos refugiados da Grande Guerra não mereceu maior atenção por parte da historiografia até recentemente e poucos registros foram deixados, mesmo porque na ocasião, os próprios desterrados sentiam como degradante tal condição e preferiam se calar. Mas nem todo deslocamento produziu consequências negativas, pois como afirma

\footnotetext{
${ }^{7}$ Os belgas foram atingidos diretamente pela ocupação do território pelos alemães. Ao todo, um milhão de belgas partiram para a França, Inglaterra ou dos Países Baixos.

${ }^{8}$ De acordo com COCHET, François, PORTE, Rémy.(dir) Dictionnaire...(2008). p.385.
} 
Marc Ferro, para os imigrantes recentes, forâneos, judeus, e outros, a guerra havia feito deles cidadãos (FERRO,1969:378). Uma década mais tarde, os movimentos migratórios continuavam intensos e, de certo modo, o desenraizamento ganhou contornos positivos quando passou a ser uma escolha individual. Intelectuais errantes e jovens endinheirados peregrinavam à Paris dos "anos loucos", que atraía estrangeiros para as músicas e festas, cabarés e exibições artísticas. Uma invasão estava ocorrendo em tempos de paz: para lá se encaminhavam jornalistas que cobriram a assinatura do Tratado de Versalhes, soldados alemães que retornavam do front, emigrados russos, pintores fauvistas, cubistas, expressionista, surrealistas, futuristas e dadá, escritores de várias nacionalidades buscando asilo (WISER, 1995: 41).

Paris tornou-se capital da intelectualidade que se reunia, sobretudo em Montparnasse e ali, como em toda a parte, uma verdadeira renovação dos costumes e valores estava em processo, intensificada pela transmissão através das ondas do rádio e das imagens do cinema mudo. A ascensão da indústria cultural e as redes de comunicação traziam a percepção de ruptura com o passado e a promessa de um futuro repleto de expectativa e novidades. As mazelas da guerra foram parcialmente esquecidas, em alguns casos, com álcool, divertimentos, esportes, jazz, consumismo e criatividade artística. O experimentalismo e a arte das vanguardas que abrilhantaram, especialmente, os círculos de Paris, Berlim, Milão nos primeiros anos do século XX, eram formas de expressão populares dentre a burguesia.

As grandes metrópoles que atraíram os escritores e artistas do pós guerra concentravam academias, galerias, museus onde imperava o tradicionalismo, ao mesmo tempo em que ofereciam oportunidades de mecenato, de empregabilidade, redes de solidariedade entre artistas émigrés e de contato com novos públicos ávidos por consumir constante novidade e renovação. Segundo Raymond Williams, nas metrópoles apresentavam-se capitais transnacionais de uma arte sem fronteiras, em Paris, Viena, Berlin, Londres e Nova York, onde surgiram estes movimentos e o investimento tecnológico que os mobilizou (WILLIAMS, 2011:5) Para estas convergiram os artistas emigrados, os exilados, naturalizados, que estavam sempre em movimento, como Marc Chagall, o diretor de Ballet Serguêi Diáguilev, o italiano Amedeo Clemente Modigliani e Pablo Picasso, que se radicaram em Paris e os artistas russos, Wassily Kandisnky, Alexej von Jawlensky, Marianne von Werefkin, que cruzaram as fronteiras da Rússia em direção à Alemanha. 
Artistas, escritores, poetas que estiveram lutando no front ou auxiliando na retaguarda, perderam seus companheiros e enterraram seus mortos, foram marcados pelo deslocamento, pelo exílio, experiências formativas da geração de Bertolt Brecht. O dramaturgo e crítico teatral flertou com as vanguardas artísticas na busca da síntese dos princípios do seu teatro épico. A condição de emigrado político lhe era familiar; vários dos amigos e interlocutores de Brecht assim viveram durante mais de quinze anos. Porém, em uma década de reviravoltas no cenário político e social, ele mesmo e todos os mais significativos intelectuais do ambiente cultural alemão estariam dispersos pelo mundo.

\section{Brecht e o ambiente alemão do pós guerra}

Bertolt Brecht não foi apenas idealizador do teatro épico proletário, ele procurou refletir sobre como se aproximar do marxismo com o objetivo de compreender o funcionamento do capitalismo e dos regimes democráticos para dar uma forma a sua arte emancipatória. ${ }^{9}$ Apesar de compromissado com a causa socialista e de crítico do reformismo, a sua formação como autor, o reconhecimento e o sucesso literário deveram-se ao ambiente liberal e democrático da República de Weimar, liderada pela social democracia, que corresponderam também aos anos mais produtivos da sua trajetória.

Eugen Berthold Bretch nasceu em Augsburg, ao sul da Alemanha, em 1898, cidade que remonta ao período romano, mas que se tornou um centro da indústria têxtil e de manufatura de papel. O pai era gerente da fábrica de papel Haindl e a família cresceu em um ambiente burguês e protestante. Quando ainda estudava no ginásio, eclodiu a Primeira Guerra, quase foi expulso por redigir um ensaio contrário à guerra. Foi nesta época que iniciou sua carreira de poeta, publicando poemas no jornal local. (EWEN, 1991:46)

Augusburg ficava nas proximidades de Munique, capital do Estado da Baviera, tendo sido palco de revoltas artesãs e de sedição religiosa, até que, ao final da Grande Guerra, foi governada pelos conselhos de trabalhadores na ocasião da revolução de 1918.(EWEN,1991:15-16). O poeta teve discreta participação no comitê revolucionário,

\footnotetext{
${ }^{9}$ Consciente de sua origem pequeno-burguesa, preferia que lhe designassem e a seu círculo de artistas marxistas como "os dialéticos entre os escritores burgueses".(PARKER,2014:253-254)
} 
enquanto trabalhava como enfermeiro em um hospital. (EWEN,1991:48-52). Durante alguns anos, viveu entre Augusburg e Munique, cidade onde ocorreu a primeira revolução soviética na Alemanha e berço do partido nazista. Brecht cursou a faculdade de medicina a partir de 1917(até 1924), porém desistiu da profissão para dedicar-se à dramaturgia.

As primeiras peças escritas por ele, como Baal (1918) e Tambores na noite (1919), A Selva das cidades (1922), Ópera dos três vinténs (1928), Ascensão e queda da cidade de Mahagonny (1930), entre outras, foram encenadas durante os anos convulsionados da República de Weimar, presidida pelo Partido Social Democrata Alemão, que negociou os termos do armistício do Tratado de Versailles. O PSDA fôra um partido de massas, o grande partido operário, majoritariamente marxista, que passou a prescrever, em primeiro plano, a luta por reformas sociais, à medida que ocupava espaços institucionais. Contudo, conforme pontuou Stackelberg (2003), a República foi implantada pela social democracia contra a esquerda revolucionária, pois o PSDA estabeleceu um governo de colaboração de classes que coordenou as ações de repressão contra os levantes nas ruas de Berlim, e em Munique, que incorreram nos assassinatos de milhares de militantes comunistas, como Karl Liebknecht e Rosa Luxemburgo. O Governo social democrata e liberal, assim como o judiciário, continuou sendo leniente com a extrema direita e com os monarquistas, em sua tentativa de golpear a república.

Até meados da década de 1920, a República de Weimar teve de enfrentar uma inflação galopante, aliada ao desemprego, que chegou ao auge em 1923. A emissão de papel moeda, com a subsequente desvalorização do marco, teve efeitos devastadores sobre o poder de compra dos trabalhadores, mas não desvalorizou as propriedades fundiárias dos Junkers, as fábricas ou as minas, tanto que a indústria se reergueu, vendendo produtos industriais mais baratos no mercado mundial. Como resultado, os ricos ficavam mais ricos, os pobres ficavam mais pobres. (ECKART \& GILMAN, 1996:17) As descrições e fotografias do período evidenciam o desabastecimento, a especulação, a miséria, a desnutrição dos trabalhadores e da classe média alemã, sobrevivendo em função de instituições de caridade.

Ainda que a economia tivesse apresentado sutil recuperação na segunda metade da década de 20, com a renegociação dos acordos de reparação e investimentos americanos no país, esta foi interrompida pela crise econômica decorrente do crash da bolsa de Nova York em 1929, que produziu um refluxo nos investimentos, mergulhando o país na recessão. A conjuntura de crise tornou mais assimilável o discurso antissemita 
e antimarxista dos nacional socialistas, que nas eleições de 1930, tornaram-se o segundo maior partido parlamentar, o que possibilitou a ascensão de Adolf Hitler através de eleições democráticas.

\section{O modernismo dos tempos de Weimar}

O período da República de Weimar foi o mais profícuo para Bertolt Brecht enquanto dramaturgo. Apesar da instabilidade econômica, um público interessado freqüentava o teatro e divertimentos, os cafés, espetáculos, shows de vaudevilles para os mais pobres e as revistas para os abastados. Dançava-se o charleston e o fox-trot, consumia-se automóveis, eletrodomésticos e novidades tecnológicas: a fotografia, rádio, cinema. Produtos culturais importados dos Estados Unidos, como o jazz e os filmes de Hollywood seduziam platéias ao redor do mundo. Particularmente em Berlim, havia os teatros e as salas de cinema que exibiam filmes expressionistas alemães, filmes americanos ou soviéticos. (ECKART \& GILMAN, 1996:21-31)

Do ponto de vista intelectual e cultural, a República de Weimar representou um período de grande efusão, criatividade e experimentalismo (GAY, 1978: 12). Tanto no ensino universitário, que foi favorecido com o emprego de influentes intelectuais, quanto nas artes, passou a simbolizar toda a heterodoxia das manifestações culturais das vanguardas e do modernismo nas artes plásticas, música, literatura, ainda que estas correntes tenham surgido já na primeira década do século. Tais grupos, apelidados de "vanguardas" (avant garde), eram autoconscientes de suas propostas, formulavam manifestos, reconheciam-se como heréticos no campo das artes e literatura, desafiavam a aristocracia e as instituições tradicionais. Em comum nutriam um sentimento antiburguês no sentido de que reagiam contra a negociação de seus livros e obras de arte como mercadoria cujo valor era determinado pelo sucesso ou fracasso das vendas. (WILLIAMS, 2011:35) Ao mesmo tempo, os autores e movimentos de vanguarda eram desprezados pela aristocracia dirigente que preferia o militarismo expresso nas artes, os desfiles, medalhas, retratos heróicos da aristocracia e o tradicionalismo acadêmico.

A Primeira Guerra, que apareceu como a promessa de progresso e antídoto contra a decadência cultural e os conflitos classistas, pois reuniria o Volk alemão em uma cruzada pela Kultur, dizimou muitos destes artistas e interrompeu as relações culturais com o resto da Europa (GAY,1978:25) Após o armistício, com o 
estabelecimento do regime democrático e a eliminação das casas aristocráticas prussianas, foi possível emergir plenamente na Alemanha uma efervescente atividade intelectual.

\section{Bertolt Brecht e a formação do teatro épico}

Nestes anos convulsionados, porém prenhes de ineditismo, Brecht estabeleceu contato, sobretudo com diretores expressionistas e dadá. Em comum com os dramaturgos de vanguarda, muitos deles dedicados à alta cultura, possuía a vontade de romper com modelos precedentes, de realizar a crítica do militarismo, do individualismo burguês e do capitalismo. Diante das críticas de que o drama e o teatro estariam em declínio - esse que foi desde o século XVIII com Schiller, Hoffman e Goethe um ícone das elevadas realizações culturais alemães - o dramaturgo concluía em um artigo do jornal liberal Vossische Zeitung de 1926 que as velhas formas deveriam ser abandonadas e uma transformação radical operada no teatro. ${ }^{10} \mathrm{O}$ novo teatro deveria se alimentar do cinema e do rádio, incorporar filmes, músicas, técnicas de palco, representação do ator, para tornar-se um meio de exercitar a razão e não de suscitar emoção, para despertar a crítica em um público proletário.

Brecht mudou-se de Munique para Berlim em 1924 para ampliar as oportunidades de trabalhar com talentosos diretores e encenar em bons teatros. Além de palco de luta política no início da república, Munique era uma cidade de intensa vida cultural, ponto de encontro das mais avançadas figuras artísticas e literárias da Alemanha, pintores, poetas, dramaturgos, jornalistas, romancistas como os irmãos Heinrich e Thomas Mann e Frank Wedekind, autor muito admirado por Brecht. Possuía cafés, teatros, óperas, exposições de arte, cabarés políticos onde poetas recitavam versos. Contudo, Berlim possuía mais teatros - um total de 32. Lá viviam dramaturgos e diretores modernistas e experimentais (Max Reinhardt, Leopold Jessner, Erwin Piscator), críticos influentes, atores e atrizes festejados, que conjugavam esforços para atualizar a cena dramática na Alemanha. As companhias de teatro russo se apresentavam, faziam teatro de rua, trabalhadores organizavam grupos teatrais - o movimento do "agit-prop", que totalizou 300 grupos com cerca de 4 mil integrantes.

\footnotetext{
${ }^{10}$ Leopold Jessner, Bertolt Brecht e Fritz Kortner "Stirbte das Drama?". Vossische Zeitung Berlim, (4/4/1926).
} 
Em Munique ele exerceu a atividade de crítico de teatro, era revisor e leitor teatral na Kammerspiele. Encaminhou-se para a capital berlinense com duas peças no currículo, Baal (1918) e Tambores na noite (1919), peça sobre um soldado que retorna da guerra em meio à revolução dos Espartaquistas. Tambores na noite estreou com sucesso de crítica em um teatro em Munique, e depois, em 1922 em Berlim, no Deutsches Theater, uma produção que não lhe agradou, mas que lhe rendeu o prêmio Kleist.

Em Berlim, trabalhou como leitor de textos no Deutsches Theater de Max Reinhardt, onde encenou também Na Selva das cidades em 1923 e começou a colaborar com o Preussisches Staatstheater. Considerava o estabelecimento mais representativo do teatro alemão, administrado pelo diretor expressionista Leopold Jessner ${ }^{11}$ (BRECHT, 1990:103). Como certa vez observou, os sucessos teatrais duravam dois invernos em uma capital que oferecia uma variedade de entretenimentos (BRECHT,1990:73), mas cuja qualidade dramatúrgica era questionável. Ele se envolveu em muitos projetos, inclusive cinematográficos, com vários colaboradores, sendo um deles Elisabeth Hauptmann, co-autora de Ópera dos três vinténs (1928). As peças que escrevia e produzia inspiravam polêmicas e se tornavam populares. $\mathrm{O}$ grande sucesso ocorreu ao estrear em 1928, no recém aberto Theater am Schiffbauerdamm em Berlim, A Ópera dos três Vinténs, baseada na Ópera do mendigo de John Gay (1728) com música de Kurt Weill.

Desde que se iniciou como crítico literário, Brecht reclamava da imprescindibilidade de se fazer comédia política que instigasse à reflexão (EWEN,1991:78). De modo algum o jovem literato permaneceu alheio às desventuras da classe trabalhadora e da miséria amargada desde o fim da guerra. Cada reformulação das peças iniciais e cada projeto que ia concretizando significaram a tentativa de aproximação da forma do teatro proletário que contribuiriam para despertar a consciência crítica do proletariado. Depois de Ópera, encenou Santa Joana dos Matadouros (1929), peça em que se constata o abandono do teatro experimental burguês e a aproximação da proposta de um teatro da classe trabalhadora (WILLIAMS, 2011:85). Da necessidade de entender melhor o funcionamento da bolsa de Chicago como pano de fundo de uma peça que estava escrevendo, Brecht empreendeu estudos de Marx, na leitura de $O$ Capital que lhe pareceu fundamental. (BRECHT, 1980:196).

\footnotetext{
${ }^{11}$ Leopold Jessner era um judeu alemão e socialista, diretor de cinema e teatro, emigrou para os Estados Unidos quando da ascensão de Adolf Hitler, onde faleceu em 1945.
} 
O dramaturgo retoma a formulação de Erwin Piscator sobre o teatro épico para expor o mundo segundo a experiência dos trabalhadores, a partir da ideia de que a democratização da arte passa pela sua iniciação nela. Trata-se de um novo teatro para um novo tipo de homem (EWEN, 1991:148) Seu objetivo é levá-lo a perceber o mundo criado pelos homens, sem subestimar sua inteligência, mostrando que este também pode ser transformado por eles.

As novas descobertas teatrais que estavam se processando no final dos anos 1920 tiveram seu percurso interrompido pela ascensão no nazismo. Raymond Williams indaga sobre o que teria acontecido com todo esse intenso desenvolvimento teatral, este movimento cultural extremamente autoconfiante que foi estilhaçado, abortado pela ascensão dos nazistas em 1933. O autor observa: “O choque e a denúncia foram substituídos pela repressão e pelo terror”. (WILLIAMS, 2011:86)

\section{A política de purificação das artes, ciência e literatura no Terceiro Reich}

Quando Adolf Hitler e o Partido nacional socialista dos trabalhadores alemães chegaram ao poder, iniciava-se o movimento para a construção de uma comunidade nacional harmônica e homogênea, purificada dos elementos indesejáveis - judeu e marxista - cuja designação era Gleichschaltung (alinhamento). Para tanto, a cúpula do novo regime assumiu uma tarefa de moldar a vida social, a fim de promover uma reforma cultural de modo a produzir o "novo homem" alemão, interrompendo o processo de decadência que se instaurara através das ideias consideradas subversivas e da degeneração física do povo.

Esta política, implementada a partir da lei de abril de 1933, atingia especificamente o ambiente intelectual e o sistema educacional com a demissão em massa de professores marxistas, de cientistas judeus que foram prontamente substituídos pelos colegas subalternos não judeus (STACKELBERG, 2003:190), intimados a se filiarem à Liga Nacional Socialista.

Nas artes, a Gleichschaltung assumiu especial importância no projeto do Terceiro Reich. Para regenerar a cultura alemã era necessário purificá-la das obras e artistas indesejáveis a partir do ideal eugênico de fortalecimento da raça. Alguns meses após a ascensão de Hitler, no início de 1933, o ministro da Propaganda Joseph Goebbels foi nomeado diretor da nova Câmara de Cultura do Reich, cujas subdivisões para a 
literatura, música, teatro, rádio, belas artes, imprensa e cinema deveriam conceder licenças para qualquer um de origem ariana que quisesse praticar uma vocação artística ou literária em conformidade ideológica com o regime. Também dentro das organizações culturais, a autocensura e os expurgos de judeus e esquerdistas foram imediatos e os diretores dos museus em todas as cidades alemães foram instruídos a remover as obras de artes “degeneradas”. (STACKELBERG, 2003,188)

A cúpula do Terceiro Reich empreendeu um programa de destruição da arte de vanguarda, associada à República de Weimar, condenada por muitos conservadores nos anos 1920 como representativa do predomínio do "niilismo", do "bolchevismo cultural" e sintoma do declínio dos padrões tradicionais. Consideravam que a arte moderna possuía uma "visão distorcida" da realidade, contaminada pelo esquerdismo judaico e que os artistas de vanguarda eram mentalmente incompetentes e transtornados.

O teatro, enquanto modalidade artística apreciada por todas as classes dispunha de um largo alcance e apelo sobre o público. Aquele que era tido como orgulho nacional, sofreu igualmente um grande baque com a demissão de diretores, produtores e atores mal vistos pelos dirigentes do Reich; alguns foram assassinados, como Hans Otto, enquanto outros procuravam não afrontar ou adular o regime. Diretores inovadores como Max Reinhardt e Erwin Piscator, ambos de origem judaica, emigraram e se estabeleceram na América, enquanto o amigo e colaborador de Brecht, Arnolt Bronnen subscreveu o voto de lealdade a Hitler em 1933.

A Câmara teatral, presidida por Otto Laudinger e o Ministério da Propaganda exerciam tutela sobre os teatros, interditando a encenação de peças de autores judeus ou banidos, enquanto favoreciam e subvencionavam a produção de peças de propaganda nazista acessíveis a milhões de trabalhadores. Privilegiavam, sobretudo, aquelas escritas pelos grandes autores germânicos, como Goethe e Schiller, que engrandeciam o sentimento de nacionalidade.

Teatro e literatura perderam alguns de seus grandes representantes contemporâneos. Grandes escritores como Thomas Mann, entre outros, já vinham sendo ameaçados de expurgo nos discursos, antes mesmo de os nazistas assumirem controle do Estado e da política. Apesar da literatura ser apreciada por vários dirigentes da alta cúpula nazista, as escolas modernas, que incorporavam a crítica social, o naturalismo, ou o expressionismo foram condenadas por não despertarem as virtudes nacionais. Em seu lugar prescreviam o gênero da literatura de combate, os romances históricos, 
exaltando o passado alemão e a literatura regional, celebrando as virtudes rurais em detrimento da vida urbana. (STACKELBERG, 2003:190)

Em fevereiro de 1933 os nazistas suspenderam o artigo 118 da Constituição de Weimar que assegurava liberdade de opinião através da palavra, escrito, impresso, imagem ou qualquer outro meio de comunicação. Logo submeteram a seção de literatura da Academia Prussiana de Artes, ao alinhamento, banindo comunistas, judeus, ou opositores políticos e estéticos, e todo aquele que se recusasse a declarar lealdade ao governo nazista. (BARBIAN, 2013:2)

Muitos escritores judeus e/ou de esquerda perderam seus empregos e foram expulsos da Alemanha, grande parte expatriada. Toda a vida intelectual e científica, de modo geral, sofreu com os expurgos, agravado pelo fechamento de editoras, ou a incorporação ideológica daquelas que não exprimissem a "alma alemã", publicando livros pertencentes a uma lista de escritores execrados. Na lista constavam 10 mil títulos proibidos que incluíam Kafka, Marx, Heine, os irmãos Thomas e Heinrich Mann, Albert Einstein e Stefan Zweig.

Em 10 de maio de 1933, a Studentenbund (liga dos Estudantes Alemães) com o apoio de Goebbels e Rosemberg organizou um ato diante da Opernplatz em Berlim para a queima de cerca de 20 mil livros de bibliotecas universitárias, reunindo uma multidão de 40 mil pessoas, ato que se repetiu em outras cidades alemães. A incineração de livros era destinada a demonstrar a rejeição da nova Alemanha à cultura intelectual "subversiva" e "degenerada" da era de Weimar (STACKELBERG, 2003:152) Autores como Bertolt Brecht, Lion Feuchtwanger e Alfred Kerr - o mais implacável crítico da Ópera dos Três vinténs- adequavam-se em todos os critérios que determinavam a condenação de suas obras como não arianas; o primeiro era marxista, o segundo, judeu, enquanto o terceiro também pertencia a esta etnia. Suas obras foram queimadas na cerimônia na Opernplatz, como as de muitos outros que buscaram o caminho do exílio.

\section{Sobrevivendo ao exílio dinamarquês}

Ao todo, 60 mil pessoas tornaram-se emigrados no ano de 1933, dentre eles militantes políticos, judeus e um contingente importante de escritores, pintores e cineastas (TRUGEON, 2010:65). A Alemanha, que na era de Weimar havia sido destino de centenas de intelectuais emigrados russos e húngaros após 1919, tornou-se local de 
partida de um êxodo inédito de acadêmicos, artistas, escritores, cientistas. (BURKE, 2017: $173-205)^{12}$

Como milhares de outros alemães, Brecht se tornou um expatriado, em decorrência da perda da cidadania alemã, retirada na quarta lista que o Reich divulgou de pessoas indignas de portar a nacionalidade, o que já tinha ocorrido a escritores como Heinrich Mann e Kurt Tucholsky (que se matou no exílio, na Suécia), Erich Weinert entre $\operatorname{outros}^{13}$.A condenação de Hitler da Lenda do Soldado Morto, canção antimilitarista que ele compôs em 1917, o tornava forte candidato à prisão. Ele se evadiu durante a noite com Helene Weigel logo depois do incêndio do Reichstag e da prisão de milhares de comunistas, após ser avisado por um conhecido do Ministério das Relações exteriores que sua prisão estaria próxima. (PARKER,2014:307)

Nas notas autobiográficas de 1941, o poeta afirmava a completa impossibilidade de continuar com as atividades literárias sob o Terceiro Reich. Todas as apresentações dramáticas foram sendo canceladas em cidades alemães e em Praga, Helene Weigel, atriz judia e esposa do dramaturgo chegou a ser detida várias horas pela polícia antes mesmo do incêndio do Reichstag. (PARKER, 2014:306) Ele perdeu um lucrativo contrato de sete anos (1929-1936) firmado com a casa de Félix Bloch Erben pelos direitos de encenação de suas peças.(PARKER,2014:255) Nas notas, contudo, justifica a sua decisão de evadir-se da Alemanha nazista, relacionando com a situação vulnerável de Helene Weigel:

Brecht é ariano; seu irmão é atualmente professor universitário na Alemanha. A esposa de Brecht que foi atriz no Staatstheater e trabalhou com Max Reinhardt, portando seu apelido de solteira, Helene Weigel, é pelo contrário, judia, motivo suficiente para que Brecht tivesse migrado da Alemanha. Entretanto, começou a combater os nazistas anos antes que Hitler tomasse o poder, e que toda a sua produção literária tivesse sido impossível sob o regime nazista. (BRECHT, 1980:202, tradução nossa)

Nesta passagem, Brecht escreve sobre si mesmo como se fôra outra pessoa, alguém de fora, o que consiste em uma maneira de seduzir seus leitores (LEJEUNE,1994: 90). Ressalta seu precoce ativismo antifascista, contudo, a ideia de que começou a combater os nazistas antes da ascensão de Hitler é exagerada, posto que não se encontra uma reflexão em seus escritos teóricos sobre este fenômeno até o período do exílio.(WHITE, 2004:77) O emprego da terceira pessoa do singular e dos

\footnotetext{
12 Às vezes foram trasladadas instituições in totum como o Instituto de Pesquisa em História Social que mudou-se para Nova York e a Escola de Warburg abrigada pela Universidade de Londres.

${ }^{13}$ No total foram 80 listas e 40 mil pessoas, que não incluía judeus deportados. Ver: “1935: Nazistas retiram a cidadania alemã de escritores e oposicionistas".(2015) Deutsche Wehling Notícias...
} 
verbos no passado condiz com a série de exercícios de repetição com os quais instruía seus atores, com a finalidade de favorecer o distanciamento. (LEJEUNE, 1994:89) Denota, outrossim, um esforço para fixar uma narrativa coerente e oficial de sua trajetória de escritor no momento em que não podia ter certeza do que reservava o futuro.

A interdição de escrever e encenar peças impele a família temporariamente para Praga, Viena, Zurique, Paris e finalmente para a Dinamarca, onde residiram em uma casa de pescadores, com telhado de palha na Skovsbostrand número 8, em Svendborg, na ilha de Fünen. Ele supunha que a guerra seria breve e que a proximidade com a Alemanha tornava Svendborg a localidade mais adequada para facilitar seu retorno quando o regime de Hitler desmoronasse. Entretanto, o exílio se prolongou por cinco anos até que a neutralidade dinamarquesa foi suspensa pela ocupação alemã. Relatava seu longo e tortuoso percurso entre 1933 e 1941, realizado com os filhos, a mulher e suas amantes:

Pese ser muito jovem - tão só dezenove anos-, meu filho já viu muitos países, e não precisamente como turista. Nasceu em Berlim, cidade de que afirma recordar-se muito bem e que não voltará a ver mais, ainda que lograsse regressar algum dia. Quando o pintor de paredes tomou o poder [Adolf Hitler], teve que voar para a Tchecoslováquia e logo à Áustria, de onde um sábio amigo nos recebeu a todos com as palavras: "Os ratos sobem no barco que trepida". Daí passamos a Suíça e logo a Dinamarca. Vivemos cinco anos em uma ilha, em uma casa de pescadores. Sob o telhado de palha havia um remo atravessado, para que a palha não voasse com as tormentas de primavera. Logo vivemos um ano na Suécia e outro na Finlândia, e ao final nos trasladamos para a Califórnia cruzando a Sibéria e o Oceano Pacífico. (BRECHT, 1980:206, tradução nossa)

A família tentou se estabelecer em diferentes países próximos, a princípio de língua alemã, Áustria, terra natal de Weigel, e Suíça porém a perseguição política e a falta de perspectivas profissionais não os tornavam boas opções. À medida que as tropas de ocupação militar nazistas avançavam, foi obrigada a fugir da Dinamarca também. A correspondência revela que sempre visaram Nova York, nos Estados Unidos, onde encontrariam patrocínio artístico e uma audiência para as peças. No entanto, demorou muitos anos para obter o visto para toda a família. De Svendborg mudou-se para a Suécia em 1939, após conseguir vistos pelo comitê social democrata sueco em troca de uma conferência no teatro de estudantes de Estocolmo, a respeito do teatro experimental. (BRECHT, 2002:33) Em seguida, quando a Suécia foi ocupada, dirigiram-se para a Finlândia, logo que as tropas do Eixo propagaram-se pela Escandinávia, fazendo uma travessia de barco até os Estados Unidos a partir de 
Moscou, em 1941, justamente dez dias antes de Hitler invadir a União Soviética.(BRECHT, 1990:424-425) Ele anotou em seu diário:

A guerra nos ia seguindo como nossa própria sombra. Esta contínua troca de países foi menos surpreendente do que se pensa. Tinha uma razão evidente nas conquistas de nossos compatriotas, levadas a cabo em um mundo onde as comunicações eram cada vez mais fáceis. Não éramos endinheirados, mas tampouco indigentes. E em todas as partes encontramos amigos. (BRECHT, 1980:206, tradução nossa)

A guerra os seguia como uma sombra, para onde a ocupação nazista avançasse, na Áustria, na França, na Escandinávia; cedo ou tarde a Europa inteira seria obstruída. Ainda que tenha logrado estabelecer-se cinco anos na Dinamarca, por mais cordiais que os nativos fossem, havia muitos simpatizantes nazifascistas nos governos, assim como a polícia secreta, que mantinham informantes e os vigiavam. Em Conversas de refugiados, um libreto cômico que simula o diálogo entre o físico Ziffel e o operário Kalle em uma cervejaria da estação ferroviária de Helsinque, os dinamarqueses são ironizados por seu humor peculiar. Aproveitaram-se da neutralidade na Primeira Guerra, diziam os personagens, constituíram um Estado do bem estar social vendendo navios para os ingleses. Não levarem a sério o fascismo até que "certa manhã surgiu nos céus com meia dúzia de aviões e ocupou tudo".(BRECHT, 2017:91)

A transitoriedade da situação da família Brecht percorrendo em poucos anos tantos países exemplifica um traço da experiência mais geral dos emigrados políticos que corrobora para prejudicar sua inserção no meio cultural, assim como a adaptação e assimilação à nova pátria. O sentimento semelhante de isolamento e desorientação que Adorno expõe em Minima Moralia, de se estar fora de casa, é agravado pelo fato de que, ao mesmo tempo, não se pode deixar de pensar nela. Muitos poemas tematizam a dor de ter a identidade subtraída, e ainda que o retorno esteja em vista, a cidade, o país que os exilados deixaram para trás, muito menos eles próprios, nunca mais seriam os mesmos.

Para o filho Stefan, anos mais jovem, aprender novas línguas e se adaptar era mais tolerável, o que não é verdade para um escritor mais velho, versado na língua alemã e acostumado a escrever para seu público.(BRECHT, 1980:206) Como repara Peter Burke, quanto mais jovem, maior a capacidade ou a vontade do emigrado se inserir na cultura local e assumir uma identidade híbrida, estruturando ou refazendo uma carreira.(BURKE, 2017:200-201) 
Em 1937 Brecht havia escrito um poema que exprimia o sentimento de um espectador dos acontecimentos e de um exilado político, Über die Bezeichnung Emigranten (Sobre a denominação de emigrante):

Eu sempre gostei do nome errado que nos foi dado: emigrantes.

Chama-se assim emigrantes. Mas nós

não emigramos por livre e espontânea vontade

Escolhemos um país diferente. Nós não somos tampouco imigrantes, mas também

Temos que ficar em um país, talvez para sempre.

Mas nós fugimos. Deslocados

somos nós, exilados.

E sem casa, um exilado deve estar no país que o acolheu.

Inquieto por isto sente-se o mais próximo possível do limite

Esperando o dia do retorno, até mesmo a menor mudança

Do outro lado da fronteira observando cada canto

Ansiosamente questiona, sem esquecimento e sem desistência

E também sem perdão pelo que aconteceu, sem perdão.

Oh, o silêncio de Sunde ${ }^{14}$

não nos enganam! Ouvimos os gritos

Longe dos seus campos até aqui. Mas somos nós mesmos

Quase como rumores

de crimes que escaparam porque

Do outro lado da fronteira. Cada um de nós

Anda na multidão com sapatos rotos

Evidência da vergonha que mancha a nossa terra

Mas nenhum de nós

Ficará aqui. A última palavra

Não foi ainda dita. (BRECHT, s.d[1937], tradução nossa)

Brecht afirma a distinção semântica entre "emigrante" e "exilado". É um testemunho vívido, trágico e, ao mesmo tempo, esperançoso da situação de exílio forçado. Os chamados de emigrados ${ }^{15}$, são na verdade exilados, foram degradados pela expulsão, "Andam na multidão com sapatos rotos/ Evidência da vergonha que mancha nossa terra". Estão atentos a qualquer mudança da situação, à espera de poder retornar, resgatar o que lhes foi tomado. Porém, não esquecem, não desistem nem perdoam, o sofrimento não os modifica, são testemunhos vivos dos crimes praticados pelo regime. Conforme ressalta Leandro Konder: "Com sua simples presença, mesmo sem agir ou falar, o exilado torna visível um problema grave, uma situação desagradável que as pessoas não têm nenhum prazer em enxergar”. (KONDER,1996:47) “A última palavra

\footnotetext{
${ }^{14}$ Refere-se à paisagem.

${ }^{15}$ Segundo Peter Burke o termo émigrés adquiriu uso corrente, não apenas na língua francesa, depois da fase do Terror (1793-1794) da Revolução Francesa, quando 180 mil opositores do regime buscaram outros países para residir.
} 
ainda não foi dita" afirmava Brecht. A palavra que lhes foi cassada poderia transpor fronteiras nacionais, seria escrita e falada, levada a platéias mundo a fora.

Como percebe Edward Said, a condição do exílio empurra o intelectual para as margens da institucionalidade, das corporações e da autoridade. (SAID, 2005:70) Para um autor teatral, escrever em outro país estando apartado de sua língua materna, concorria para diminuição das oportunidades: os melhores diretores e atores estavam espalhados por vários países; surgia a necessidade de contar com boas traduções e com subvenções de associações e de amigos para encenar peças e ajudá-lo a sustentar-se. Procurou resgatar os valores relativos aos direitos autorais das peças encenadas ou publicadas, sem muito êxito. Como anotou em sua autobiografia:"Não éramos endinheirados, mas tampouco indigentes. E em todas as partes encontramos amigos". As relações de amizade e solidariedade entre emigrados eram uma forma fundamental de sobrevivência material que atenuava a sensação de isolamento.

$\mathrm{Na}$ casa de pescador em Svendborg, ele e Helene Weigel frequentemente entretinham amigos para discutir política, teatro, marxismo, revolução e a situação dos exilados e da resistência na Alemanha. Dentre os convidados estavam Benjamin, Döblin, Korsch, Brentano, Eisler, Kläber.(PARKER:2014:321-322) Podia dar continuidade dos trabalhos literários, ainda que com dificuldades, contando com proventos da American Guild for German Cultural Freedom ${ }^{16}$, fundado por judeus alemães no exílio.(BRECHT,1990:291-293;328-329) Brecht, por outro lado, remetia ajuda financeira para alguns amigos, como Walter Benjamin, embora não pudesse ajudar sempre, como foi o caso de Slatan Dudow.

A sua rede de relações foi fundamental para sobrevivência da família: amigos indicavam-lhe teatros para encenar, trocavam opiniões sobre livros, remetiam publicações e revistas e indicavam oportunidades de aulas remuneradas. Muitos intelectuais do círculo íntimo de Brecht e Weigel estavam espalhados por vários países e capitais: Karl Korsch em Londres, na Dinamarca e nos Estados Unidos; Hanns Eisler em Praga, Viena, Paris, Londres, Moscou, Espanha, México e Dinamarca e enfim em Nova York; Slatan Dudow ${ }^{17}$ em Paris e depois na Suíça; Carola Neher ${ }^{18}$ em Praga e

\footnotetext{
${ }^{16}$ American Guild foi fundada em 1935 por Hubertus Prinz zu Loewenstein e cada vez mais assumiu as funções de uma organização de ajuda para exilados escritores, artistas e cientistas.

${ }^{17}$ Slatam Dudow foi um diretor búlgaro, marxista, membro do Partido Comunista alemão, preso em um campo de concentração e extraditado pelos nazistas logo que chegaram ao poder em 1933.
} 
depois na União Soviética; E. Piscator em Moscou, Paris e Estados Unidos. Nesta época, as visitas que recebiam e a possibilidade de encenar em teatros em Copenhagen, tornavam o refúgio menos solitário e as diferenças entre as posições dos emigrados alemães menos perceptíveis quanto seriam, anos mais tarde, nos Estados Unidos ${ }^{19}$.

Para Brecht, a possibilidade de restabelecer estes contatos dava-lhe a impressão de que fazia parte de uma autêntica comunidade de escritores e artistas, um Panteão de grandes vultos. No poema "A Emigração dos Poetas" ele se incluiu entre uma lista de notáveis expatriados, marginalizados e perseguidos escritores da literatura universal:

Homero não tinha morada

E Dante teve que deixar a sua.

$\mathrm{Li}-\mathrm{Po}$ e Tu-Fu andaram por guerras civis

Que tragaram 30 milhões de pessoas

Eurípides foi ameaçado com processos

E Shakeaspere, moribumdo, impedido de falar

Não apenas a Musa, também a polícia

Visitou François Villon.

Conhecido como "o Amado"

Lucrécio foi para o exílio

Também Heine, e assim também

Brecht, que buscou refúgio

Sob o teto de palha dinamarquês. (BRECHT,2000:121)

Os poemas produziam como efeito alguma esperança, ao menos, de que não seria esquecido pela posteridade. Mas no presente persistia a dificuldade de emplacar sucessos novos ou antigos no exterior. A barreira da língua, a distância de um público qualificado, as incertezas do presente e o estranhamento cultural podem ter levado, por exemplo, Stefan Zweig, escritor austríaco de grande popularidade na Alemanha, radicado em Petrópolis (RJ) em 1941, a cometer suicídio. Na iminência de ser capturado por agentes franquistas, Walter Benjamin ingeriu morfina durante uma fuga pelos Pirineus no outono de 1940. O suicídio no caso de intelectuais perseguidos e malditos é evocado por Benjamin, não como renúncia, mas como paixão heróica. (BENJAMIN, 2000:11).

Benjamin e Brecht nutriam admiração e afeição um pelo outro e conviveram em várias ocasiões durante o exílio. Travaram conhecimento, provavelmente, em maio de

\footnotetext{
${ }^{18}$ Carola Neher foi uma atriz que atuou na Ópera dos três vinténs. Quando Hitler subiu ao poder, exilouse em Praga e na União Soviética, onde foi acusada de trotskista e acabou sendo enviada para prisão russa e morreu de tifo em 1942.

${ }^{19}$ A divergência se expressaria, sobretudo, com os irmãos Mann, que eram, segundo Brecht, nostálgicos da república de Weimar e com os expoentes da Escola de Frankfurt cuja perspectiva seria, sobretudo burguesa.
} 
1924, em Berlim, por intermédio de Asja Lacis, diretora de teatro russa e amante de Benjamin. Encontraram-se algumas vezes nos círculos intelectuais e grupos de debates literários que reuniam judeus e não judeus alemães. $\mathrm{O}$ crítico e o poeta estreitaram o contato a partir de 1929, uma conexão que desagradava os amigos mais íntimos de Benjamin. $^{20}$

No exílio dinamarquês, Benjamim passou diversas vezes temporadas em Svendborg em 1934, 1935 e 1938, quando passava o dia todo com a família na casa de telhado de palha, jogava partidas de xadrez com o anfitrião, enquanto comentavam os trabalhos em andamento de um e de outro ${ }^{21}$. Benjamin remeteu sua famosa biblioteca com centenas de livro para casa dos Brecht, enquanto transitava entre Paris e Ibiza. Em uma carta a Benjamin datada de 1933, em que busca convencê-lo a se estabelecer na localidade, o poeta assim descreveu seus dias em Svendborg:

Helli acha que você poderia arrumar-se aqui com 100kr (60 RM, 360 francos). Mais ainda, a biblioteca de Svendborg conseguirá para você qualquer livro. Nós temos rádio, jornais, carteado, e em breve seus livros, pequenos cafés e lareira, uma linguagem extraordinariamente fácil, e o mundo está se acabando mais silenciosamente por aqui. (BRECHT,1990:152-153, tradução nossa)

Quando soube que Benjamin se suicidou, Brecht já não mantinha contato com ele pelo menos desde 1939. Anotou em seu diário em agosto de 1941, de forma pouco emotiva, que Benjamin havia se envenenado em uma cidadezinha na fronteira espanhola (Port Bou) e que um amigo lhe emprestara o manuscrito de seu último artigo, versando sobre pesquisa histórica. Tratava-se, provavelmente, de Teses sobre a filosofia da História, que Brecht julgou bastante claro, enfocando questões complexas com simplicidade, apesar das "metáforas” e do "judaísmo". (BRECHT, 2005:7)

No diário de trabalho de Brecht constam impressões pessoais de livros e conversas, afazeres e material que ele coletava para peças em desenvolvimento. Durante a estadia dinamarquesa terminou algumas peças e trabalhos pendentes, como A alma boa de Setsuan, A vida de Galileu; realizava pesquisas, como aquelas para o seu Negócios do Sr Julio César e leu entusiasmado A filosofia da história de Hegel.

\footnotetext{
${ }^{20}$ Adorno e Scholem, mas também Ernst Bloch e Kracauer, julgavam a influência do poeta perigosa para o pensamento de Benjamim. Na correspondência trocada entre Adorno e Benjamin e Scholem e Benjamin consideravam que Benjamin era muito dependente do amigo e que, segundo eles, Brecht tentava levar Benjamin a incorporar o materialismo histórico e seu método. (WIZISLA,2013:26-31).

${ }^{21}$ Benjamin admirava toda a obra teatral de Brecht, porém desaprovou o seu Negócios do Sr Julio César. Brecht estava muito entusiasmado quanto aos estudos sobre Baudelaire e sobre a reprodutibilidade da obra de arte que Benjamin elaborava, mas fez duras críticas a respeito de seu ensaio sobre Kafka.
} 
Produziu o livrinho em dois capítulos intitulado Conversas de refugiados e Ruth Berlau imprimiu as Poesias de Svendborg sob subscrição. Do exílio ele orientava, através de correspondência, diretores a encenar suas peças, mas nem sempre com resultados satisfatórios.Anos mais tarde, quando encontrava-se na Califórnia, escrevia lamentandose a Karl Korsche: "Meu isolamento aqui é horrível, comparado a Hollywood, Svendborg era uma metrópole".(BRECHT,1990: 351)

Durante todo o período da guerra os diários revelam como Brecht acompanhou de perto através dos jornais ou em debates com outros expatriados os movimentos do exército alemão e, depois da derrota, os acordos que selaram a rendição. À medida que a guerra se tornava fato inevitável, mais aparecem nos diários reflexões sobre a luta de classes, sobre a natureza do fascismo enquanto faceta do capitalismo, sobre o pacto de não agressão firmado entre Stálin e Hitler, assim como críticas à concepção do socialismo soviético e à passividade do proletariado alemão diante do nazismo.

No poema "Aos que vierem depois de nós", escrito durante os anos de exílio dinamarquês, Brecht alude ao tempo dos exilados como "tempos sombrios" e insere a experiência de sua geração em uma dimensão histórica e temporal de sucessão geracional que remete às Teses sobre a Filosofia da História de Benjamin, inclusive porque critica diretamente o conformismo.

Vocês, que vão emergir das ondas/em que nós perecemos/ pensem/ quando falarem das nossas fraquezas, nos tempos sombrios/ de que vocês tiveram a sorte de escapar./Nós existíamos através da luta de classes,/ mudando mais seguidamente de países que de sapatos, desesperados!/ quando só havia injustiça e não havia revolta. (BRECHT,2011:2012-213)

O círculo de sociabilidades em que Brecht incorporou-se na chegada a América era composto por importantes figuras literárias alemães, escritores considerados "burgueses", mas cujo prestígio poderia fortalecer a causa antifascista. Em carta a Thomas Mann ele assevera a importância dos exilados organizarem a resistência:

Os crimes da Alemanha de Hitler são patentes. Nós exilados fomos os primeiros a chamar a atenção para eles e temos que convocar um extenso e incrédulo mundo a combatê-lo. E somos nós que sabemos sobre os crimes destes monstros contra seu próprio povo, e a resistência do nosso povo ao regime. (BRECHT, 1990:374-375)

Brecht discordava das ideias de Thomas Mann, porém apelava a ele por mobilização, porque os intelectuais emigrados sabiam dos crimes de Hitler, poderiam influenciar a opinião pública nos países democráticos, combatendo, de fora a máquina de propaganda que Goebbels. Os dissidentes poderiam integrar um movimento 
internacional de denúncia dos crimes que estavam sendo cometidos. Escrevia no seu diário de trabalho em 19 de fevereiro de 1939:

Os emigrados dormem, mas é um sono agitado. Há certos pesadelos: que Hitler não fique sem troco miúdo, que seja eleito o papa errado, que Churchill desmorone. $\mathrm{O}$ cavalinho em que as pessoas gostam de apostar, o favorito, é "o desejo de paz do povo alemão". (BRECHT, 2002:26)

Em outras palavras, ainda predominava a apatia entre os exilados, limitavam-se a torcer e esperar pelo melhor. Precisavam transpor este obstáculo, romper com o conformismo. O teatro demonstrou ser a melhor forma de expor os crimes e injustiças do regime nazista, ainda que o idealizador do teatro épico fosse obrigado a fazer concessões ao seu método. Não obstante, avaliava que o teatro proletário estava mantendo vivo o teatro no exílio, quando diretores expressionistas aderiram ao teatro burguês. (BRECHT, 2002:13)

\section{0 "teatro de emigração" e a resistência através da literatura}

Os intelectuais de esquerda eram particularmente visados pelas autoridades do Reich. Brecht acreditava, desde o final dos anos 1920, em uma frente ampla de forças progressistas contra o fascismo, que defendeu no poema "Quando o fascismo se tornava cada vez mais forte"(1926-1933). A recusa da frente pelos líderes da social democracia, que preferiram não "usar o terror vermelho contra o branco", acabaria por fazê-los aceitar os nazistas, muito embora crescesse "a vontade de lutar dos proletários" e também da base da social democracia, desobedecendo às lideranças partidárias. (BRECHT, 2000:95)

No exílio, editou e colaborou com jornais antifascistas e literários, como o Das Wort, para o qual, muitas vezes, enviava em vão seus comentários. Comparecia a reuniões de mobilização contra a guerra, como o Congresso Internacional de Escritores. No II Congresso ocorrido em Paris em julho de 1937, Brecht discursou, denunciando os bombardeios a aldeias e o massacre contra o povo espanhol impetrado pelos mesmos fascistas que, na Alemanha, ocuparam a sede de sindicatos, assassinaram em praça pública e torturaram trabalhadores nos porões da Gestapo. O poeta acrescentava: "Os ditadores fascistas exportam hoje ao proletariado estrangeiro os mesmos métodos previamente aplicados ao proletariado de seu país”. (PÉREZ,2008:272) Caracterizou em seu discurso as ditaduras alemã e italiana como favoráveis ao capital, promovendo a 
destruição de sindicatos e, ao mesmo tempo, aos monumentos de cultura. A ameaça à democracia e às liberdades foi acompanhada pelo ataque à cultura e a privação dos trabalhadores dos meios de produção cultural. Afirmava, assim, que os produtores culturais, que até então se mantiveram à margem dos acontecimentos, deveriam combater seus opressores e aniquilá-los. (PÉREZ,2008:272)

Com a preocupação de denunciar o massacre em solo espanhol, empenhou-se em viabilizar a encenação entre 1937 e 1938, em Paris, da peça Os Fuzis da Senhora Carrar que situou durante a Guerra civil espanhola. Brecht já vinha declamando poemas de resistência no rádio ou os contrabandeando para dentro da Alemanha. Em seu país, Goebbels colocara a rádio, assim outros meios de comunicação, à serviço da propaganda do regime. O sem fio poderia incorporado pelo proletariado na luta antifascista, na disputa das consciências, já que poderia transmitir e receber mensagens.

Em Svendborg, escrevia os capítulos de um romance satírico sobre o "ditador" Júlio César, "protótipo de todos os ditadores", ao qual daria o nome de Die Geschäfte des Herrn Julius Caesar (Os negócios do sr.Júlio César).(BRECHT,1990:278-279) Conforme informava a American Guild for German Cultural Freedom, a peça não era uma biografia dissimulada de Mussolini ou Hitler, demandava muita pesquisa histórica. (BRECHT, 1990:292) Seu propósito era, não apenas informar o leitor sobre as guerras e a democracia, mas também fornecer um retrato da persistência da escravidão, conduzindo à escravização geral de todas as classes da sociedade.

Um projeto ao qual se dedicou com afinco, pois aparece sua menção várias vezes ao longo dos diários e da correspondência, foi um conjunto de cenas curtas escritas entre 1935 e 1938, que mais tarde reuniria na peça Terror e miséria no terceiro Reich (Furcht und Elend des Dritten Reiches) ${ }^{22}$. O dramaturgo trabalhou com recortes de jornal, fotos e reportagens de rádio para fazer, em parceria com Margarete Steffin, sua amante e colaboradora, esquetes curtas, transformadas em incidentes dramáticos e reais, que visavam diretamente aos emigrados (EWEN, 1991:300) Brecht cuidou minuciosamente da produção da peça, correspondendo-se com os diretores Dudow (Paris) e Max Reinhardt (Nova York) na ocasião em que as esquetes eram encenadas em cidades fora da Alemanha, ao final dos anos 1930 e nos anos da guerra, primeiramente em Paris, Londres, Estocolmo e depois, em Nova York em 1945.

\footnotetext{
${ }^{22}$ Chegou a 27 cenas, mas algumas foram cortadas para serem reunidas e publicadas em 1945 com o título definitivo. Porém, em 1996 outras 5 cenas não publicadas foram encontradas.
} 
Seguir as especificações do teatro épico era um procedimento muito caro para Brecht, mas nos anos que antecederam à guerra havia uma causa urgente, qual fosse, a denúncia de Hitler e de sua política interna. O Führer tinha simpatizantes e admiradores em todas as partes do mundo, não apenas entre as comunidades de origem alemã. Muitos países tidos como democráticos permaneciam indiferentes ao rearmamento, à política anti-semita e ao expansionismo nazifascista para fazer face a um possível fortalecimento do comunismo. Brecht explicava sua posição política em uma nota autobiográfica de 1941:

Nunca pertenceu a um Partido político e agora tampouco pertence. Contra os nazistas já tinha publicado poemas e escreveu uma peça: Terror e miséria do Terceiro Reich, que ilustra em 27 cenas independentes e ambientadas em casas, hospitais, salas de audiência, campos de concentração, escolas, fábricas, quartéis, etc. a falta de liberdade de quase todas as camadas do povo alemão sob a ditadura. (BRECHT, 1980:202)

A peça destoa dos princípios usuais do teatro épico por situar-se abertamente na Alemanha sob o regime nazista, encorajando a empatia dos espectadores para com as tragédias do cotidiano. Já o teatro épico procurava produzir o efeito do estranhamento, apelando para a historicidade e transferindo a narrativa para outros contextos espaciais diversos daquele familiar aos espectadores. Porém, abdicou do seu projeto porque aquela lhe pareceu a maneira mais realista de representar os crimes do nazismo e lançar o público à reflexão.

A peça estreou na noite de 21 e 22 de maio de 1938. Oito esquetes foram apresentadas na Salle d'Iena, em Paris, sob o título de 99\%, que aludia ao resultado do plebiscito que Hitler impôs para a aprovação do Anschluss ${ }^{23}$ no mês de abril daquele ano, título que Brecht hesitou em aceitar por considerar inadequado. Talvez sua insatisfação se explique melhor porque o título 99\% traduz melhor uma situação de consenso do que de coerção, resultado este desejado por Hitler, que se utilizou amplamente dos plebiscitos para legitimar sua política racista e anticomunista.

Slatam Dudow ${ }^{24}$ foi escolhido para dirigir a peça, com música de Paul Dessau e com a atuação da esposa Helene Weigel, que também representou em Os fuzis da Senora Carrarar ${ }^{25}$. Dudow dirigira em 1931 o filme Kuhle Wampe ou a Quem pertence

\footnotetext{
${ }^{23}$ Anschluss (1938) retirava a autonomia da Áustria e a tornava departamento da Alemanha.

${ }^{24}$ Slatam Dudow foi um diretor búlgaro, marxista, membro do Partido Comunista alemão, preso em um campo de concentração e extraditado pelos nazistas logo que chegaram ao poder em 1933.

${ }^{25}$ Os demais membros do elenco eram Erich Schoenbank, Steffi Spira, Guenter Ruschin, Hans Almann, Friedel Perrari, Nora Reissmann, Jup Leininger, Erich Berg, segundo noticiou o jornal francês L’humanité.21/05/1938.p.2.
} 
o Mundo?, escrito por Brecht e Ernst Ottwlat, primeiro filme alemão marxista que foi censurado como potencialmente perigoso no ano seguinte (ECKART \& GILMAN, 1996:103). Em Paris desde 1934, Dudow dedicava-se a realizar um cinema proletário e mostrar as condições de vida deficitárias dos trabalhadores alemães. Sem sair da Dinamarca, Brecht procurou interferir na produção da peça, na escolha dos atores e na data de estréia. Após o sucesso internacional da Ópera dos três vinténs alertava que precisava manter um padrão, até mesmo para que o sucesso de Terror e Miséria no Terceiro Reich ecoasse na América do Norte e despertasse interesse em produzi-la por lá. Achava que Paris e os Estados Unidos eram os únicos lugares em que sua produção poderia ser apreciada, pois o medo havia dominado a Europa (BRECHT, 1990:280) Seu rigor não podia tolerar trupes amadoras, que não dominavam o idioma alemão. Cogitava atores alemães experientes com quem estava acostumado a trabalhar como Felix Bressart, Ernst Busch e Helene Weigel, que saberiam exatamente como interpretar no teatro épico, já que não poderiam contar com a presença física e a orientação do autor, que estava na Dinamarca, durante os ensaios. Por carta, discutia com Dudow sobre as possibilidades de recepção de esquetes pelo público, sugeria a ordem da apresentação das cenas e repreendia o diretor pela falta de notícias concretas sobre a produção. (BRECHT, 1990:283)

Não considerava Terror e miséria no Terceiro Reich um drama depressivo, posto que mostraria a resistência em todos os setores da sociedade alemã. Ao finalizar todas as cenas, julgava que este era um drama representativo da literatura dos refugiados. (BRECHT, 1990:286) Walter Benjamin, que esteve presente à estréia, publicou uma crítica no Neuen Weltbühne em que afirmava que foi o senso da situação histórica que uniu o público na première, após cinco anos de exílio. Marcava o recomeço do "teatro de emigração", o qual deveria se ocupar do drama político, favorecido pela técnica do teatro épico brechtiano. (BENJAMIN,1998:37) O jornal Deutsche Volkszeitung, diário editado pelo Partido Comunista alemão no exílio, saudou o ciclo teatral como uma proclamação antifascista de uma frente unida. (EWEN, 1991:302)

Brecht discutiu sua intenção com Slatan Dudow, em carta de março e abril de 1938. A peça mostrava a fragilidade do Terceiro Reich em todas as suas partes e aspectos, assim como a crescente resistência de cada setor da população. Destacava que o regime era sustentado apenas pela violência (BRECHT,1990:p.281),violência esta que crescia como reação à resistência: "Não apenas os nazistas recorrem à violência, eles 
devem recorrer a violência".(BRECHT,1990: 282) Ainda que ressaltasse o aspecto coercitivo do regime, sobretudo contra seus opositores, social democratas, comunistas e liberais, o dramaturgo conhecia o efeito que os meios de comunicação e a poderosa estrutura corporativa produziu sobre as pessoas comuns. Dizia a Dudow que foi sua opção mostrar os pontos de resistência e poupar os espectadores do "infinitamente deprimente espetáculo dos muitos que são entusiastas, e ainda maior número dos que foram neutralizados".(BRECHT, 1990: 282)

Brecht reconhece, em suas anotações de 1938, não apenas a dimensão de classe do regime, sua faceta coercitiva e repressiva, mas igualmente o efeito ideológico produtor de consenso, em torno do qual operavam, não apenas os ideólogos profissionais, mas milhões de pequenos burgueses e trabalhadores manuais que se encontravam politicamente "envolvidos": barbeiros que eram membros ativos da SA, artesãos e pequenos lojistas, em suas inúmeras associações de classe, assim como professores e engenheiros. Cooptados do Partido Nacional Socialista, as "pessoas comuns" atuavam como braços do partido em vários níveis e sentiam-se parte da “comunidade nacional".

Brecht acompanhava com interesse a evolução do fascismo, mantinha-se bem informado pelos jornais alemães e pela rádio, pelos amigos que lhe escreviam do círculo de intelectuais alemães exilados. As notícias que vinham de lá eram terríveis, companheiros fuzilados, escritores e artistas pareciam se resignar. Desejava mostrar que o fato de que na Alemanha de Hitler não houvesse oposição generalizada e ostensiva, até porque esta foi silenciada, não diminuía o fato de que ela existia, de que as pessoas sofriam e se indignavam.

\section{Considerações finais}

Com a ascensão do nazifascismo, a cultura, que na Alemanha desfrutou de um momento de efervescência durante a República de Weimar, foi um dos primeiros e mais importantes domínios da vida social a ser afetada, através da política de alinhamento, acompanhando o aniquilamento dos sindicatos e da democracia. Este evento concorreu para o êxodo de milhares de acadêmicos, artistas, escritores, cientistas já no primeiro ano do novo regime de extrema direita. Diante das privações e limitações do exílio, as relações de amizade e solidariedade entre emigrados constituíam uma forma 
fundamental de sobrevivência, no sentido de atenuar o isolamento e permitir, ainda que com dificuldades, a continuidade dos trabalhos literários.

Atribuindo significado à condição de exilado, na poesia Über die Bezeichnung Emigranten Bertolt Brecht propõe a distinção semântica entre "emigrante" e "exilado, constatando que escritores deste tempo não emigravam por livre e espontânea vontade, passavam privações e estavam sempre no limite porque não estavam em casa. Apesar de tudo, não se conformariam, estariam à espera do possível retorno. Nas cartas trocadas com outros intelectuais, nos diários de trabalho, nos poemas, discursos, peças e demais trabalhos literários, Brecht revela a preocupação central de romper o conformismo, de organizar a comunidade intelectual alemã no exílio para protestar em todas as oportunidades, aproveitando a projeção literária de que gozavam.

Do exílio na Dinamarca, ele escreveu peças que tinham o intuito de mostrar a dimensão de classe do regime, a repressão e a violência contra o proletariado que, não obstante, fazia parte da máquina de guerra que servia para oprimi-lo. Para ele o teatro parecia ser a melhor forma de expor os crimes e injustiças do nazismo. Após a encenação de Terror e miséria no Terceiro Reich em 1938, em Paris, Benjamin anunciou o recomeço do "teatro de emigração". Ainda que o idealizador do teatro épico fosse obrigado a fazer concessões ao seu método, avaliava que o teatro proletário estava mantendo vivo o teatro no exílio, que ao representar de maneira realista os crimes do nazismo, lançaria o público à reflexão.

Quando a condição de intelectual exilado passou a ser um fenômeno social com o "grande êxodo" (BURKE, 2017:183), e uma presença cotidiana nas principais capitais culturais do mundo, Zurique, Londres, Paris, Nova York, este assume o papel de porta voz dos vitimados do seu país. Em parte, graças a estes emigrados, o resto do mundo se inteirou do que se passava na Alemanha nazista, no momento em que "o pintor de paredes", como Brecht apelidou Hitler, era eleito o homem do ano pela revista nova iorquina Times em 1938.

\section{Fontes}

BRECHT, Bertolt. (1980) Diários 1920-1922. Notas autobiográficas 1920-1954. Barcelona: Editorial Crítica. (1990) Letters 1913-1956.London: Methuen.

(1991) Teatro Completo. Rio de Janeiro: Paz e Terra. volume 5.

. (1993) Journals 1934-1955. London, Methuen.

(2000) Poemas 1913-1956. São Paulo:Editora 34. 
(2002) Diário de Trabalho.1938-1941.Rio de Janeiro: Rocco.vol.1.

(2004) Über die Bezeichnung Emigranten. Disponível em http://projekte.aeg-

reutlingen.de/exil2004/brecht.html Acesso em 13 de abril de 2015.

(2005) Diário de Trabalho.1941-1947.Rio de Janeiro: Rocco.vol.2.

. (2017) Conversa de refugiados. São Paulo:Editora 34.

"Hier Soir au deuxième séance du Congress International des écrivains à Paris.(1937)

L'HUMANITÉ, Organe du Parti Communiste (21-5-1938)". Paris,n. 14.397. Disponível em: https://gallica.bnf.fr/ark:/12148/bpt6k4074512/f2. p.2

\section{Referências Bibliográficas}

“1935: Nazistas retiram a cidadania alemã de escritores e oposicionistas".(2015) Deutsche Wehling. Notícias. Disponível em: http://www.dw.de/1935-nazistasretiram-a-cidadania-alemã-de-escritor.Acesso em 23/07/2015.

ADORNO, Theodor W.(s.d) Minima Moralia. Lisboa: Edições 70.

BARBIAN, Jan-Pieter. (2013) The Politics of Literature in Nazi Germany:Books in the media Dictatorship. New York, London, Nova Delhi, Sidney:Bloomsbury.

BENJAMIN, Walter.(2000) Modernidade e os modernos. $2^{\mathrm{a}} \mathrm{ed}$, RJ:Tempo Brasileiro.

BURKE, Peter. (2017)Perdas e ganhos.Exilados e expatriados na história do conhecimento na Europa e nas Américas.1500-2000.São Paulo:Unesp.

COCHET, François, PORTE, Rémy.(dir) (2008) Dictionnaire de La Grande Guerre. 1914- 1918. Paris:Robert Laffont.

DOSSE, François. (2004) La historia intelectual después de del linguistic turn.Historia e Graphia.UIA, n.23, p.17-54. (2009) O desafio biográfico. São Paulo, Edusp.

ECKARDT, Wolf von \& GILMAN, Sander L.(1996) A Berlim de Bertolt Brecht.Um album dos anos 20. Rio de Janeiro: José Olympio.

EWEN, Frederic.(1991) Bertolt Brecht, sua vida sua arte e seu tempo. São Paulo:Editora Globo.

FERRO, Marc.(1969) La Grande Guerre, 1914-1918.Paris, Gallimard.

GAY, Peter. (1978) A cultura de Weimar. Rio de Janeiro: Paz e Terra.

GOMES, Angela. (org.) (2004)Escrita de si, escrita da história. Rio de Janeiro:FGV.

PEREZ, Ana. El exilio alemán. Textos literarios y políticos (2008).Madrid, Barcelona, Buenos Aires, Marcial Pons, 2008.

LEJEUNE, Phillipe.(1994) El pacto autobiográfico y otros studios. Madrid: MagazulEndymion.

McKEOWN, Adam. (2004) Global Migration, 1846-1940. Journal of World History. University of Hawai'i Press Vol. 15, No. 2 (Jun., 2004), pp. 155-189 Disponível em https://www.jstor.org/stable/20068611 Acesso em: 27 jul.2019.

JEANPIERRE, Laurent (2008.) O lugar da exterritorialidade. In: RODRIGUES, Helenice, KOLER, Heliane(org.) Travessias e cruzamentos culturais. A mobilidade em questão. RJ: FGV.

KONDER, Leandro. A poesia de Brecht e a história. Rio de Janeiro: Jorge Zahar, 1996.

PARKER, Stephen. Bertolt Brecht: a literary life. London: Bloomsbury, 2014.

SAID, Edward. (2003) Reflexões sobre o exílio. In: Reflexões sobre o exílio e outros ensaios. São Paulo: Companhia das Letras.

(2005) Exílio intelectual: expatriados e marginais. In: Representações do intelectual. São Paulo: Companhia das Letras. 
SIMMEL, Georg. O Estrangeiro. Revista Brasileira de Sociologia da Emoção. vol 4, n.12, dez 2005.p.265-270.

STACKELBERG, Roderick.(2003) A Alemanha de Hitler. Origens, interpretações, legados.Rio de Janeiro: Imago.

TODOROV, Tzvetan. (1999) O homem desenraizado. São Paulo, Record.

TRUGEON, Mélanie. (2010) "Un cinéaste antifasciste à Paris: Slatan Dudow (19341939)", 1895. Mille huit cent quatre-vingt-quinze, 60, 2010. Disponível em: http://1895.revues.org/3867. Acesso em 3/01/2014.

WILLIAMS, Raymond (2011). Política do modernismo: contra os novos conformistas. São Paulo: Editora Unesp.

WHITE, John. (2004) Bertolt Brecht's Dramatic Theory.New York: Camden House.

WISER, William. (1995)Os anos loucos. Paris na década de 20.Rio de Janeiro, José Olympio.

WIZISLA, Erdmut. (2013) Benjamin e Brecht, a história de uma amizade. São Paulo, Edusp.

Artigo recebido em 03 de agosto de 2019.

Aprovado em 13 de novembro de 2019.

DOI:10.12957/intellectus.2019.44392 